\title{
DEFINITION OF TERRORISM AND EU COUNTER-TERRORISM POLICY
}

\author{
Violeta Vasiliauskiené $\dot{~}^{1}$, Martynas Vasiliauskas ${ }^{2}$ \\ ${ }^{1}$ Dr., Assoc. professor, Kaunas College, e-mail: Violeta.vasiliauskiene@go.kauko.lt, \\ Kaunas, Lithuania \\ ${ }^{2}$ Dr., Assoc. professor, Kaunas College, e-mail: martynas.vasiliauskas@go.kauko.lt \\ Kaunas, Lithuania
}

\begin{abstract}
The article dwells on the problem of the definition of terrorism. This term, though usually commonly understandable, is a legal term, the definition of which is not yet universally adopted. The threat of terrorism, taking upon different forms, is always relevant and the efforts to contain it continue. Thus the definition of the phenomenon and its elements is crucial in such efforts. The analysis is relevant as internationally this term is still not defined in one universal legally binding document and there are questions on its exact scope. The article explains two elements that are usually considered essential in defining terrorism. Furthermore, the article dwells on the EU efforts to contain the threat and in particular on its efforts to prevent terrorism - that is, actions taken to counter terrorist radicalisation.
\end{abstract}

Keywords: EU counter-terrorism policy, prevention of terrorism, radicalisation, terrorism, terrorist aims.

\section{Introduction}

The problem of terrorism seems to be relevant notwithstanding the period we live in. In 2001 it was the events of 9/11, later bombings in Madrid and Moscow in 2004, in 2012-2013 it was the rise of Islamic State, or ISIS, which managed to take hold of large portions of territory in the Middle East and in 2015 to carry out the Paris attacks. Therefore the threat, taking upon different forms, is always relevant and the efforts to contain it continue. Thus the definition of the phenomenon and its elements is crucial in such efforts. The analysis is relevant as internationally this term is still not defined in one universal legally binding document and there are questions on its exact scope.

Furthermore, speaking about EU response to such threat, it can be noted that the efforts of EU intensified significantly since the attacks on 11 September 2001 and especially after the Madrid and London bombings in 2004 and 2005, EU started to take active part in the global fight against terrorism.

The aim of the article is to establish what elements constitute the definition of terrorism and how does EU address the issue of terrorism.

The tasks of the article are: 
1) to provide the main elements of the definition of terrorism in international law;

2) to analyse main aspects of EU counter-terrorism policy;

3) to describe EU efforts in the prevention of terrorism.

\section{The problem of definition of terrorism}

\subsection{Efforts in reaching a universal definition of terrorism at UN level}

The question of terrorism is one of the most problematic questions in international law and international politics (UN Commission on Human Rights, 2001). It raises very different emotions, from trying to achieve radical change to fury and condemnation on other part of spectrum (Barnidge, 2008). The term "terror" was used to describe the politics of intimidation used during French revolution. In 1937 the states tried to adopt the Convention for the Prevention and Punishment of Terrorism, but it did not come into force. "It described terrorism as "criminal acts directed against a State and intended or calculated to create a state of terror in the minds of particular persons or a group of persons or the general public." The convention specified the kinds of anti-state actions that were to be considered acts of terror (e.g., attacking public officials, heads of state and their families, or the destruction of public facilities)." (World Digital Library, 2020). As we will see later, the main elements of the definition of terrorism were already present in this definition.

At the UN level, a special ad hoc committee was created by UN GA resolution in 1996 No. 51/210 for reaching an agreement regarding the definition of terrorism by negotiating the Comprehensive Convention on International Terrorism. Thus far the Convention has not yet been adopted. It is aimed to criminalize the crime of terrorism but the significance of it lies in the fact that this Convention establishes the first universal definition of terrorism (Walter, 2003). The Article 2 defines that "any person commits an offence within the meaning of the present Convention if that person, by any means, unlawfully and intentionally, causes: (a) Death or serious bodily injury to any person; or (b) Serious damage to public or private property, including a place of public use, a State or government facility, a public transportation system, an infrastructure facility or to the environment; or (c) Damage to property, places, facilities or systems referred to in paragraph 1 (b) of the present article resulting or likely to result in major economic loss, when the purpose of the conduct, by its nature or context, is to intimidate a population, or to compel a Government or an international organization to do or to abstain from doing any act." (United Nations, 2013) 
Furthermore, the threat or attempt to commit the offence named above, accomplice in such crimes or contributing to such crimes should be criminalized as well.

The convention stresses the importance of "criminalization of terrorist offences, making them punishable by law and calling for the prosecution or extradition of the alleged perpetrators." (United Nations Office on Drugs and Crime, 2020).

Terrorism should be criminalized without reference to "exceptions to such criminalization on political, philosophical, ideological, racial, ethnic, religious or similar grounds." (United Nations, 2013) The Convention also foresees that the Member States should "cooperate, exchange information and provide each other with the greatest measure of police and judicial assistance in the prevention, investigation and prosecution of terrorist acts." (United Nations, 2013)

\subsection{The elements of definition of terrorism}

There are two elements of the definition of terrorism that can be distinguished from various definitions adopted at regional organisations and in national legislation. The objective element means that there was a criminal act causing harm committed, and the subjective element requires a certain motivation and aims of the perpetrators of the act (Walter, 2003).

Regarding the objective element, it can be noted that the definitions that are in force provide for different list of acts considered terrorist, but the common thing is that the act itself should be serious enough to be considered terrorist. The object of such act in some definitions is life or health of a person, when sustaining serious damage, and in other conventions the list of objects is wider and encompasses damage to environment and property, or the acts which may cause danger to national resources. (Vasiliauskiené, 2014) C. Walter (2003) notes that there is a tendency in national legislations to include acts which are disastrous to public infrastructure. But it should be noted that "an overly broad definition runs the risk that legitimate forms of protest against government decisions where crimes are committed or damage to the state occurs (such as during a general strike) could be identified as terrorism, so the definition of terrorism should include the criterion of serious harm, which would help to distinguish such acts from forms of peaceful protest which also seek to change state policy on the relevant issues, but without causing damage equivalent to that caused by a terrorist attack." (Vasiliauskiené, 2014)

Speaking about the subjective element, it is this element that distinguishes the crime of terrorism from so called "regular" crimes, like homicide, destruction of property, theft and so on. Thus, the common 
denominator among all the regional conventions in terms of the stated purpose would be two main aims - that is, the intent to intimidate the population and, secondly, to compel the government (and, in some cases, international organization) to take certain actions or to refrain from them. Wider definition of the objective risks jeopardizing the alignment of the crime of terrorism with other crimes.

\subsection{The problems with the adoption of the convention and with the definition of terrorism in general}

One of the problems when discussing the Convention on Terrorism, as well as in general in debates on terrorism is the debate as to whether the definition of terrorism can be used to define the actions of the state and its officials. There are different provisions in international instruments regarding the qualification of state actions as terrorist. 1991 The draft Code of Crimes against Peace and Security of Humanity drafted by the UN Commission on International Law provided that the State may commit a crime of terrorism, but terrorism was removed from the project as early as 1996. Most documents indirectly exclude state action from its scope. This applies to actions taken by a state against its own citizens (then the international element is not met), or actions taken during an international armed conflict (some treaties provide that they do not apply in an armed conflict). This issue is also related to the exclusion of armed forces from the scope of the conventions prohibiting terrorist attacks and providing a definition of terrorism (Vasiliauskiené, 2014).

Article 3 of the draft Comprehensive Convention on Terrorism, which deals with exceptions to the scope of the Convention, further indicates another question that is not yet resolved. The main issue of disagreement is the issue of the actions of nations fighting for independence, as some states argue that the Convention must make a clear distinction between what constitutes terrorism and what is a legitimate struggle between nations to exercise their right of self-determination or fight foreign occupation.

\subsection{Existing sectoral conventions on terrorism}

Besides the search for general definition of terrorism, there were treaties adopted which prohibit certain manifestations or forms of terrorism.

Alongside the search for a common definition of terrorism, another system of international treaties related to terrorism has been developed international treaties that prohibit specific forms of terrorism. Currently, 14 such conventions can be counted. These treaties do not define terrorism in 
general terms, but prohibit relevant acts that are commonly described as terrorist. The Conventions also lay down the respective obligations of the Member States in relation to the prohibition of such acts, the duty to prevent such crimes and the duty to cooperate in punishing them, usually expressed as an obligation to extradite or prosecute persons who have committed such acts. These conventions prohibit relevant terrorist acts. (Vasiliauskienè, 2014). Such conventions include 1963 Tokyo Convention on Offenses and Certain Other Acts Committed on Board Aircraft; 1970 Hague Convention for the Unlawful Seizure of Aircraft; 1973 Convention on the Prevention and Punishment of Crimes Against Internationally Protected Persons, Including Diplomatic Agents; 1979 Convention Against the Taking of Hostages; 1988 Protocol for the Suppression of Unlawful Acts against the Safety of Fixed Platforms Located on the Continental Shelf (supplements the Rome Convention); 1997 Convention for the Suppression of Terrorist Bombings; 1999 Convention for the Suppression of the Financing of Terrorism, and others.

\section{EU counter terrorism policy}

\subsection{The development of EU counter-terrorism policy}

Terrorism is a threat that poses risk to EU states, thus they have been acting together in this field. The legal basis for the action of EU has appeared in the so-called Maastricht, or EU treaty, adopted in 1993, which introduced new fields into EU competence, among them the competence in the field of Freedom, security and justice. The development of EU counter-terrorism policy was greatly influenced by the events of 9/11 in the USA and later by 2004 Madrid and 2005 London bombings. The EU counter-terrorism policy in general evolved in the face of new threat stemming mostly from jihadist type terrorism. In the aftermath of 9/11, already in "November 2001, the European Council adopted an Action Plan on Combating Terrorism and an EU Counterterrorism Strategy was agreed in December 2005, following the terrorist attacks in Madrid and London." (Decade in counter terrorism, p. 196). In December 2003 European Security Strategy was adopted which listed terrorism as one of the top threats, and called for action to counter it, as it was also reiterated in its update in 2008. As Argomaniz, et. al. (2014, p. 196) state it, "Terrorism is also a key element in the 2010 Internal Security Strategy. It is no surprise that in a 2010 European Commission stocktaking exercise on EU measures specifically aimed at fighting terrorism, a conservative estimate would put the number of initiatives spanning across all of the EU's former three pillars to more than 80." 
Currently, the main policy document of this field is the EU Counter-Terrorism Strategy, adopted by European Council in 2005. The EU commits to fighting terrorism globally, while respecting human rights and ensuring that the citizens of EU are able to live in an area of freedom, security and justice. The strategy is built around four main fields:

“1) Prevent people from turning to terrorism and stop future generations of terrorists from emerging;

2) Protect citizens and critical infrastructure by reducing vulnerabilities against attacks;

3) Pursue and investigate terrorists, impede planning, travel and communications, cut off access to funding and materials and bring terrorists to justice;

4) Respond in a coordinated way by preparing for the management and minimisation of the consequences of a terrorist attack, improving capacities to deal with the aftermath and taking into account the needs of victims." (European Commission, 2020)

\subsection{Definition of terrorism and terrorist offences in EU legislation}

The definition of terrorism in EU legislation is aimed at harmonisation of the criminal legal acts in EU Member states. EU has competence on this question based on Article 83 of the Treaty on the Functioning of EU, which gives the European Parliament and the Council the competence to adopt minimum rules concerning the definition of particularly serious crime with a cross-border dimension, of which terrorism is an example. The current definition of terrorist offences is outlined in the Directive (EU) on combating terrorism 2017/541, adopted on 15 March 2017. This Directive replaced the Framework Decision 2002/475/JHA as the cornerstone of the EU countries' criminal justice response to counter terrorism, and amended parts of Decision 2005/671/JHA on the sharing of information and cooperation concerning terrorist offences. The Directive aims to adapt the EU rules on the definition of terrorism in the current evolution of terrorist threats, and as such establishes minimum rules concerning the definitions of offences and related sanctions in this area. Furthermore, it also introduces measures of protection, support and assistance for victims of terrorist attacks. The states have an obligation to include in their criminal codes the minimum elements of the crime of terrorism as indicated in the abovementioned Directive.

The definition of terrorism in this act is composed of two elements - of the list of serious acts/offences (objective element) and of the description of the terrorist aim (subjective element), which both are necessary to consider a particular action a terrorist crime. The objective element includes 
“attacks upon a person's life which may cause death; attacks upon the physical integrity of a person; kidnapping or hostage-taking; causing extensive destruction to a government or public facility, a transport system, an infrastructure facility, including an information system, a fixed platform located on the continental shelf, a public place or private property likely to endanger human life or result in major economic loss; seizure of aircraft, ships or other means of public or goods transport; manufacture, possession, acquisition, transport, supply or use of explosives or weapons, including chemical, biological, radiological or nuclear weapons, as well as research into, and development of, chemical, biological, radiological or nuclear weapons; release of dangerous substances, or causing fires, floods or explosions, the effect of which is to endanger human life; interfering with or disrupting the supply of water, power or any other fundamental natural resource, the effect of which is to endanger human life; illegal system interference, [...], and threatening to commit any of the acts listed [above]" (European Parliament and Council, 2017). Furthermore, the subjective element should include one of the following "seriously intimidating a population; unduly compelling a government or an international organisation to perform or abstain from performing any act; seriously destabilising or destroying the fundamental political, constitutional, economic or social structures of a country or an international organisation." (European Parliament and Council, 2017).

Furthermore, there is a list of related offences which should also be criminalized which also include offences related to the participation in terrorist group or direction thereof; the distribution of the message aimed at inciting a terrorist offence; solicitation and recruitment of another person to commit a terrorist offence; provision of receiving training for terrorist purposes; travelling for the purposes of terrorism, or organisation and facilitation of such travel; provision and collection of funds with the intention that they will be used to commit terrorist offences. (European Parliament and Council, 2017, art. 4-12).

\subsection{Measures aimed at the prevention of terrorism}

This pillar of counter-terrorism efforts in EU aims to combat radicalisation and recruitment to terrorism. The term itself is not in all cases similarly understood, there are broader and narrower definitions available. "Some authors and experts refer now to violent radicalisation as a path that inherently involves concrete violent behaviour, while others qualify the mere acceptance of certain ideas which condone or justify violence as an indicator of violent radicalisation. For some authors and experts, the path to violent radicalisation is an individual one, whereas for 
others it is considered to be a collective process." (Bakker, 2015, p. 284). Radicalisation is influenced by various factors, which can roughly be divided into internal and external factors. "According to Ranstorp, some of the internal factors relate to issues such as polarising public rhetoric, stigmatization or identity crises. The external dimension includes Western military interventions, the role of global media and cyberspace and a general perception of injustice suffered by Muslims." (Bakker, 2015, p. 284). Personal and collective grievances are dominant in both internal and external dimensions.

The analysis on radicalisation also dwells on the catalysts that contribute to radicalisation of a person. Catalysts mostly happen in external levels, as well as in the social and individual levels. They speed up or catapult radicalization of individuals who are in advanced phase of violent radicalisation process. They might lead to recruitment or to trigerring events. (Bakker, 2015).

The first document indicating measures against radicalisation was the 2004 EU action plan on countering terrorism. The document indicates the need to identify factors which contribute to recruitment of the members of terrorist groups both within the EU and internationally, after which a long-term strategy may be evaluated. According to this plan various studies were conducted in 2004-2006 in this field. Furthermore, the cooperation in good governance was sought with Arab world in order to address factors outside EU contributing to terrorism. The last group of action indicated was to develop and implement a strategy to promote cross-cultural and inter-religious understanding between Europe and the Islamic World. (Council of the EU, 2004).

Another document indicating the need to combat radicalisation was the 2005 European Union Counter-Terrorism Strategy. As mentioned, the strategy has four pillars: prevent, protect, pursue and respond. The prevent pillar implies actions in order to "prevent people turning to terrorism by tackling the factors or root causes which can lead to radicalisation and recruitment, in Europe and internationally". (Council of the European Union, 2005a). The document indicates the opinion of the Council that EU may help in the field of countering radicalisation by helping co-ordinate national policies; share information and determine good practice. The key priorities foreseen in the document in prevention are developing common approaches to spot and tackle problem behaviour, in particular the misuse of the internet; addressing incitement and recruitment in particular in key environments, that is, in prisons, places of religious training or worship, notably by implementing legislation making these behaviours offences, developing a media and communication strategy to explain better EU policies; promoting good governance, democracy, education and economic 
prosperity through Community and Member State assistance programmes; develop intercultural dialogue within and outside the Union, continue research in the field. (Council of the European Union, 2005a; Pranevičiene \& Vasiliauskiene, 2019).

The document specifically addressing the problem of radicalisation was EU Strategy for Combating Radicalisation and Recruitment to Terrorism, which was adopted in 2005, and revised in 2008 and 2014, which lays the foundations for an enhanced involvement of civil society in tackling and countering radicalisation. (Council of the EU 2005b). The strategy states that in order to counter radicalization and terrorist recruitment, the EU resolves to "disrupt the activities of the networks and individuals who draw people into terrorism; ensure that voices of mainstream opinion prevail over those of extremism; promote yet more vigorously security, justice, democracy and opportunity for all." (Council of the European Union, 2005b).

2010 EU Internal Security Strategy, prepared by the European Commission (2010) also addresses radicalisation. The second aim indicated in the strategy is to "prevent terrorism and address radicalisation and recruitment." (European Commission, 2010). Among the measures of empowerment of the communities to prevent radicalisation and recruitment are important because de-radicalisation "requires close cooperation with local authorities and civil society and empowering key groups in vulnerable communities. The core of the action on radicalisation and recruitment is - and should remain - at national level." (European Commission, 2010). The Commission affirms that "several Member States are developing work streams in this area, and certain cities within the EU have developed local community-based approaches and prevention policies." (European Commission, 2010).

Furthermore, the prevention of terrorism includes also fight against the financing of terrorism. "Countering the financing of terrorism is a core component of the EU's strategy in the fight against terrorism." (European Commission, 2020a). The EU Commission has adopted in 2016 an Action plan on strengthening the fight against terrorist financing. "The action plan aims at detecting and preventing the movement of funds and other assets; helping law enforcement trace financial movements; and disrupting the sources of revenue." (European Commission, 2020a). The legal framework was also strengthened to include acts on the definition of terrorism, improvements in anti-money laundering acts, etc. 


\subsection{Current issues in the prevention of terrorism}

Terrorism has been and continues to be a threat to European Union Member States. The European Union Terrorism Situation and Trend Report 2019, which is prepared every year by Europol indicates that 13 people were killed in terrorist attacks in the EU in 2018 which signifies a decrease compared to 2017. All the attacks were jihadist in nature and committed by individuals acting alone. (Europol, 2019). Europol indicates that in addition to the seven completed attacks, EU Member States reported 16 foiled jihadist terrorist plots, which illustrates the effectiveness of counter terrorism efforts. "The significant number of thwarted attacks and the so-called Islamic State's (IS) continued intent to perpetrate attacks outside conflict zones indicate that the threat level across the EU remains high." (EUROPOL, 2019).

Regarding radicalisation, one problem that was mentioned in Europol's report was the radicalisation of people in Europe, especially in prisons. "In October 2018, 25 inmates were identified in 17 different prisons all over Spain belonging to a jihadist network. The network was composed of prisoners with prior records for jihadist terrorism-related crimes and of inmates convicted of other criminal offences, who presumably became radicalised in prison." (Europol TESAT 2019). It was also noted that Italy reported also having this problem where the increase of number of prisoners showing support of IS was observed. Thus even after loosing much of the territory that it once controlled, ISIS remains a threat through its former members and newly radicalised individuals.

\section{Conclusions}

The question of terrorism is one of the most problematic questions in international law and international politics. The first universal definition of terrorism is provided in the draft Comprehensive Convention on Terrorism, which defines terrorism as act including a serious damage to persons or property and completed with a specific aim. Unfortunately, this definition is not yet in force.

There are two elements of the definition of terrorism that can be distinguished from various definitions adopted at regional organisations and in national legislation. The objective element means that there was a criminal act causing harm committed, and the subjective element requires a certain motivation and aims of the perpetrators of the act.

One of the problems when discussing the Convention on Terrorism, as well as in general in debates on terrorism is the debate as to whether the definition of terrorism can be used to define the actions of the state and its 
officials. The general tendency seems to exclude the actions of the state from the purview of the conventions. Another important question is whether the actions of nations fighting for independence, as some states argue that the Convention must make a clear distinction between what constitutes terrorism and what is a legitimate struggle between nations to exercise their right of self-determination or fight foreign occupation.

The definition of terrorism in EU legislation is aimed at harmonisation of the criminal legal acts in EU Member states. EU has competence on this question based on Article 83 of the Treaty on the Functioning of EU, which gives the European Parliament and the Council the competence to adopt minimum rules concerning the definition of particularly serious crime with a cross-border dimension, of which terrorism is an example.

Main document specifically addressing the problem of radicalisation on EU level was EU Strategy for Combating Radicalisation and Recruitment to Terrorism, adopted in 2005, which lays the foundations for an enhanced involvement of civil society in tackling and countering radicalisation. The strategy indicates that in order to counter radicalisation EU resolves to disrupt the activities of the networks and individuals who draw people into terrorism; ensure that voices of mainstream opinion prevail over those of extremism; promote yet more vigorously security, justice, democracy and opportunity for all.

\section{References}

1. ARGOMANIZ, J., BURES, O., \& KAUNERT, C. (2015). A Decade of EU Counter-Terrorism and Intelligence: A Critical Assessment, Intelligence and National Security, 30:2-3, pp.191-206.

2. BAKKER, E. (2015) EU Counter-radicalization Policies: A Comprehensive and Consistent Approach?, Intelligence and National Security, 30:2-3, pp.281-305.

3. BARNIDGE, R. P. JR. (2008) Terrorism: Arriving at an Understanding of a Term. In Glennon, M.J.; Sur, S. (eds.) (2008) Terrorisme et droit international/Terrorism and international law. Leiden/Boston: Martinus Nijhoff Publishers.

4. Council of the European Union. (2004). EU Plan of Action on Combating Terrorism. No. 10586/04. Retrieved August 19, 2020, from http://register.consilium.europa.eu/doc/srv?l=EN\&f=ST\%2010586\%202004\%2 OINIT

5. Council of the European Union. (2005a). The European Union Counter-Terrorism Strategy. No. 14469/05. Retrieved August 19, 2020, from https://register.consilium.europa.eu/doc/srv?l=EN\&f=ST\%2014469\%202005\% 20REV\%204

6. Council of the European Union. (2005b). The European Union Strategy for Combating Radicalisation and Recruitment to Terrorism. No. 14781/1/05. Retrieved August 19, 2020, from http://register.consilium.europa.eu/doc/srv?l=EN\&f=ST\%2014781\%202005\%2 0REV\%201 
7. European Commission. (2010). Communication from the Commission to the European Parliament and the Council: The EU Internal Security Strategy in Action: Five steps towards a more secure Europe. No. $\operatorname{COM}(2010) 673$ final. Retrieved August 19, 2020, from https://eur-lex.europa.eu/legal-content/EN/TXT/?uri=celex:52010DC0673

8. European Commission. (2020) Counter Terrorism and radicalisation. Retrieved August 19 , 2020, from https://ec.europa.eu/home-affairs/what-we-do/policies/counter-terrorism_en

9. European Commission. (2020) Fight against the financing of terrorism. Retrieved August 19, 2020, from https://ec.europa.eu/home-affairs/what-we-do/policies/counter-terrorism/figh t-financing-terrorism_en.

10. European Parliament and Council. (2017). Directive (EU) 2017/541 of 15 March 2017 on combating terrorism and replacing Council Framework Decision 2002/475/JHA and amending Council Decision 2005/671/JHA. Official Journal of the European Union, L 88, 31 March 2017.

11. EUROPOL. (2019) European Union Terrorism Situation and Trend Report. Retrieved August 19, 2020, from https://www.europol.europa.eu/activities-services/main-reports/terrorism-situ ation-and-trend-report-2019-te-sat

12. PRANEVIČIENĖ, B., \& VASILIAUSKIENĖ, V. (2019). Challenges for European security policy: issues of the prevention of radicalization in the context of the right to religious education. JOURNAL OF SECURITY AND SUSTAINABILITY ISSUES. 2019 June Volume 8 Number 4.

13. UN Commission on Human Rights. (2001). Sub-Commission on the Promotion and Protection of Human Rights. Terrorism and Human Rights. Progress report of the Special Rapporteur, Kalliopi K. Koufa. 27 June 2001. No. E/CN.4/Sub.2/2001/31. Retrieved August 19, 2020, from https://www.refworld.org/docid/3d5a2cd30.html

14. United Nations. (2013). Draft comprehensive convention against international terrorism. Retrieved August 19, 2020, from https://www.ilsa.org/Jessup/Jessup08/basicmats/unterrorism.pdf

15. United Nations Office on Drugs and Crime. (2020) Treaty-based crimes of terrorism - universal counter terrorism instruments. Retrieved August 19, 2020, from

https://www.unodc.org/e4j/en/terrorism/module-4/key-issues/treaty-based-cr imes-of-terrorism.html

16. VASILIAUSKIENĖ, V. (2014). Kova su terorizmu tarptautinės humanitarinès teisès kontekste. Doctoral dissertation. Vilnius: Vilnius University.

17. WALTER, C. (2003). Defining Terrorism in National and International Law. In: Walter, C. et. al. Terrorism as a Challenge for National and International Law: Security vs. Liberty? Berlin: Springer.

18. World Digital Library. (2020) Convention for the Prevention and Punishment of Terrorism. Retrieved August 19, 2020, from https://www.wdl.org/en/item/11579 